\title{
Sequential Congo Red Elimination by UASB Reactor Coupled to Electrochemical Systems
}

\author{
Itzel Celeste Romero-Soto ${ }^{1,2} \mathbb{D}$, Celestino García-Gómez ${ }^{1,3, * \mathbb{D}}$, Luis Humberto Álvarez-Valencia ${ }^{4}$ (D), \\ Edna Rosalba Meza-Escalante ${ }^{5}$, Luis Alonso Leyva-Soto ${ }^{1}$, Maria Angeles Camacho-Ruiz ${ }^{2}$ (D), \\ María Olga Concha-Guzmán ${ }^{2}$, Ruth Gabriela Ulloa-Mercado ${ }^{1}$, Lourdes Mariana Díaz-Tenorio ${ }^{1}$ \\ and Pablo Gortáres-Moroyoqui ${ }^{1, *(D)}$
}

check for updates

Citation: Romero-Soto, I.C. García-Gómez, C.; Álvarez-Valencia, L.H.; Meza-Escalante, E.R.; Leyva-Soto, L.A.; Camacho-Ruiz, M.A.; Concha-Guzmán, M.O.; Ulloa-Mercado, R.G.; Díaz-Tenorio, L.M.; Gortáres-Moroyoqui, P. Sequential Congo Red Elimination by UASB Reactor Coupled to Electrochemical Systems. Water 2021, 13, 3087. https://doi.org/10.3390/ w13213087

Academic Editor: Chin-Pao Huang

Received: 23 September 2021

Accepted: 30 October 2021

Published: 3 November 202

Publisher's Note: MDPI stays neutral with regard to jurisdictional claims in published maps and institutional affiliations.

Copyright: (c) 2021 by the authors. Licensee MDPI, Basel, Switzerland. This article is an open access article distributed under the terms and conditions of the Creative Commons Attribution (CC BY) license (https:/ / creativecommons.org/licenses/by/ $4.0 /)$.
1 Departamento de Biotecnología y Ciencias Alimentarias, Instituto Tecnológico de Sonora, 5 de Febrero 818 sur, Ciudad Obregón 85000, Mexico; itzel.romero@academicos.udg.mx (I.C.R.-S.); luis.leyva@itson.edu.mx (L.A.L.-S.); ruth.ulloa@itson.edu.mx (R.G.U.-M.); lourdes.diaz@itson.edu.mx (L.M.D.-T.)

2 Centro Universitario del Norte, Universidad de Guadalajara, Km. 191, Mexico 45D No. 23, Colotlán 46200, Mexico; angeles_camacho@cunorte.udg.mx (M.A.C.-R.); mocg@cunorte.udg.mx (M.O.C.-G.)

3 Facultad de Agronomía, Universidad Autónoma de Nuevo León, Francisco I. Madero S/N, Ex Hacienda el Cañada, Ciudad General Escobedo 66050, Mexico

4 Departamento de Ciencias Agronómica y Veterinarias, Instituto Tecnológico de Sonora, 5 de Febrero 818 sur, Ciudad Obregón 85000, Mexico; luis.alvarez@itson.edu.mx

5 Departamento de Ciencias del Agua y Medio Ambiente, Instituto Tecnológico de Sonora, 5 de Febrero 818 sur, Ciudad Obregón 85000, Mexico; edna.meza@itson.edu.mx

* Correspondence: Celestino.garciagm@uanl.edu.mx (C.G.-G.); pablo.gortares@itson.edu.mx (P.G.-M.)

Abstract: Response surface methodology was investigated to determine the operational parameters on the degradation of Congo red dye (CR) and chemical oxygen demand (COD) in two electrochemical systems evaluated individually on effluent pretreated by an up-flow anaerobic sludge blanket (UASB) reactor. The UASB reactor was fed with $100 \mathrm{mg} \mathrm{L}^{-1}$ of CR and was operated for 12 weeks at different hydraulic residence times (HRTs) of $12 \mathrm{~h}, 10 \mathrm{~h}$, and $8 \mathrm{~h}$. Once stabilized at an HRT of $8 \mathrm{~h}$, the effluent was collected, homogenized, and independently treated by electrooxidation (EO) and electrocoagulation (EC) cells. On both electrochemical systems, two electrode pairs were used; solid for EC (Fe and stainless-steel) and mesh electrodes for $\mathrm{EO}\left(\mathrm{Ti} / \mathrm{PbO}_{2}\right.$ and $\left.\mathrm{Ti}\right)$, and the effect of intensity (A), recirculation flow rate $\left(\mathrm{mL} \mathrm{min}^{-1}\right)$, and experimental time ( $\mathrm{min}$ ) was optimized on response variables. The maximum efficiencies of sequential systems for COD degradation and CR decolorization were $92.78 \%$ and $98.43 \%$ by EC and $\geq 99.84 \%$ and $\geq 99.71 \%$ by EO, respectively. Results indicate that the coupled systems can be used in textile industry wastewater treatment for the removal of dyes and the decolorized by-products.

Keywords: azo dye; electrooxidation; electrocoagulation; Congo red; UASB; wastewater

\section{Introduction}

The textile industry generates significant environmental pollution due to the excessive amount and diversity of colorants and color auxiliaries used during dyeing processes. In recent years, clothing demand and the use of azo-type dyes, which represent around 60-70\% of the total dye used industrially, have increased [1]. The presence of small amounts of dyes in aquatic systems reduces light penetration, which inhibits photosynthesis, affecting gas solubility and, consequently, trophic chain [2,3]. Azo dyes are synthetic, highly toxic, and present resistance to degradation by oxidizing agents, photodegradation, and biological systems [4,5]. In addition, the textile industry consumes high amounts of water, and in places with scarce drinking water, textile effluents are generally recycled to reduce requirements, which increases the risk of exposure to these compounds [6]. Congo red (CR) is a synthetic benzidine-based anionic diazo dye widely used by the textile, paper, and 
plastic industries due to its high fixation in cotton. It is used in measurement as a natural dye and as an indicator. CR is difficult to biodegrade, and it is metabolized to benzidine, a human carcinogen that is an irritant to eyes and skin and can cause allergic reactions $[7,8]$.

Biological, chemical, electrochemical, and physical systems have been evaluated in different studies [9]. Adsorption methods have been the most studied, using several materials $[2,3,7,8,10-13]$. However, high doses of adsorbents may be required $[9,14,15]$, regeneration of the adsorbent is difficult and expensive, additional treatment methods for the mineralization of dyes are necessary, and is not applicable to a wide variety of dyes $[16,17]$. The application of aerobic systems does not allow the effective degradation of azo dyes by their electrophilic nature [18]. However, under anaerobic conditions, azo dyes are susceptible to duffer reductive biotransformation using up-flow anaerobic sludge blanket (UASB) reactors [19-21] and other systems [22]. The UASB reactors have the economic advantage of not requiring oxygen; they generate low biomass and can withstand high loads of organic matter compared to other systems [23]. Under anaerobic conditions, azo dyes are reduced to aromatic amines $[20,21,23,24]$, which presents the need to use a posterior system for the complete oxidation/elimination of these toxic compounds.

For the complete removal of azo dyes, biological sequential anaerobic-aerobic treatment has been used. However, aromatic amines have substituents with nitro and sulfonic groups; these are highly recalcitrant for aerobic bacteria, which does not allow the efficient mineralization of these compounds in a biological aerobic post-treatment [22]. Nonetheless, the coupled system by electrochemical-biological methods, with the theoretical principle to convert the dye molecules to readily biodegradable compounds by electrochemical treatment $[25,26]$, cannot be used with high loads of organic matter because of the competition with the dyes. Furthermore, the application of the electrochemical process may promote the mineralization of azo dyes to more toxic compounds, which limits efficient removal in the biological system.

The aromatic amines and color remnant from UASB reactors and the other anaerobic systems can be removed using electrochemical systems, in which electrooxidation contributes to the mineralization of contaminants and allows entrapment by electrocoagulation [27]. During the electrooxidation process, $\mathrm{OH}^{-}$radicals (highly oxidizing agents) are generated on the anode surface and are responsible for carrying out more than $90 \%$ of the oxidation (direct), until $\mathrm{CO}_{2}$ and $\mathrm{H}_{2} \mathrm{O}[28,29]$. The material of the anode is an essential factor in the generation of $\mathrm{OH}^{-}$radicals. Diamond doped boron (BDD) is the anode with the highest reported efficiency. However, it has the disadvantage of having a very elevated cost. $\mathrm{PbO}_{2}$ coated anodes have a removal rate close to BDD, are of low cost, and can be used for the efficient oxidation of azo dyes and aromatics amines. On the other hand, in the electrocoagulation process by applying electrical current, adsorbents $\left(\mathrm{Fe}(\mathrm{OH})_{3}, \mathrm{Fe}(\mathrm{OH})^{2+}\right.$, $\mathrm{Fe}(\mathrm{OH})_{2}{ }^{+}$and $\mathrm{Fe}_{2}(\mathrm{OH})_{2}{ }^{4+}$ [30]) are generated on the Fe anode. For this type of dye, Fe has a higher affinity. The adsorbents generated will trap amines and other contaminants that could not be eliminated in the preliminary stage. Some studies of UASB reactors coupled to electrochemical systems have achieved decolorization of color above $92 \%$ and of COD $\sim 67-90 \%$ on different wastewater effluents [31-33]. The objective of this work was to decolorize the CR dye by a sequential system using a conventional UASB reactor as a biological treatment to remove the organic matter and promote the reduction of the dye, coupled with two electrochemical treatments (electrooxidation and electrocoagulation), operated individually, as post treatment.

\section{Materials and Methods}

\subsection{Experimental Unit and Operation Conditions}

Biological treatment was conducted in a $900 \mathrm{~mL}$ cylindrical UASB reactor made of Plexiglas material (Figure 1). The bioreactor was inoculated with $340 \mathrm{~g}$ of anaerobic sludge, equivalent to $23.3 \mathrm{~g}$ volatile suspended solids (VSS) $\mathrm{L}^{-1}$. The sludge was collected from an industrial UASB reactor installed in a brewery. The bioreactor was fed with a solution composed of $153.85 \mathrm{mg} \mathrm{L}^{-1}$ of CR (65\% Sigma Aldrich) and $1 \mathrm{~g} \mathrm{~L}^{-1}$ of 
sodium acetate (99\% purity Faga Lab) as a carbon and energy source. In addition, the solution was prepared according to the basal medium described by Alvarez and Cervantes [34], with the following composition $\left(\mathrm{g} \mathrm{L}^{-1}, \geq 99.0 \%\right.$ Sigma Aldrich): $\mathrm{NaHCO}_{3}$, 1.68; $\mathrm{NH}_{4} \mathrm{Cl}, 0.3 ; \mathrm{KH}_{2} \mathrm{PO}_{4}, 0.2 ; \mathrm{MgCl}_{2} \cdot 6 \mathrm{H}_{2} \mathrm{O}, 0.03 ; \mathrm{CaCl}_{2}, 0.1$; and $1 \mathrm{~mL} \mathrm{~L}^{-1}$ of trace elements solution. Trace elements solution contained $\left(\mathrm{mg} \mathrm{L}^{-1}\right): \mathrm{FeCl}_{2} \cdot 4 \mathrm{H}_{2} \mathrm{O}, 2000 ; \mathrm{H}_{3} \mathrm{BO}_{3}$, 50; $\mathrm{ZnCl}_{2}, 50 ; \mathrm{CuCl}_{2} \cdot 2 \mathrm{H}_{2} \mathrm{O}, 38 ; \mathrm{MnCl}_{2} \cdot 4 \mathrm{H}_{2} \mathrm{O}, 500 ;\left(\mathrm{NH}_{4}\right) 6 \mathrm{Mo}_{7} \mathrm{O}_{24} \cdot 4 \mathrm{H} 2 \mathrm{O}, 50 ; \mathrm{AlCl}_{3} \cdot 6 \mathrm{H}_{2} \mathrm{O}$, 90; $\mathrm{CoCl}_{2} \cdot 6 \mathrm{H}_{2} \mathrm{O}, 2000 ; \mathrm{NiCl}_{2} \cdot 6 \mathrm{H}_{2} \mathrm{O}, 92 ; \mathrm{Na}_{2} \mathrm{SeO} \cdot 5 \mathrm{H}_{2} \mathrm{O}, 162 ;$ EDTA, 1000 ; and $1 \mathrm{~mL} \mathrm{~L}^{-1}$ of $\mathrm{HCl}, 36 \%$ ( $\geq 99.0 \%$ Sigma Aldrich). The solution was adjusted to $\mathrm{pH} 7$. Three hydraulic residence times (HRTs) of $12 \mathrm{~h}, 10 \mathrm{~h}$, and $8 \mathrm{~h}$ were evaluated during 12 weeks of the total operation. Once the anaerobic system had stabilized at an HRT of $8 \mathrm{~h}$, its effluent was periodically collected in containers of $1.5 \mathrm{~L}$ and was frozen at $4{ }^{\circ} \mathrm{C}$ in the dark. For subsequent treatment in electrochemical systems, a frozen container was taken for each experiment, and it was gradually thawed in the dark, homogenized, and evaluated under the parameters established in the experimental design.

\section{Continuous Anaerobic Treatment}

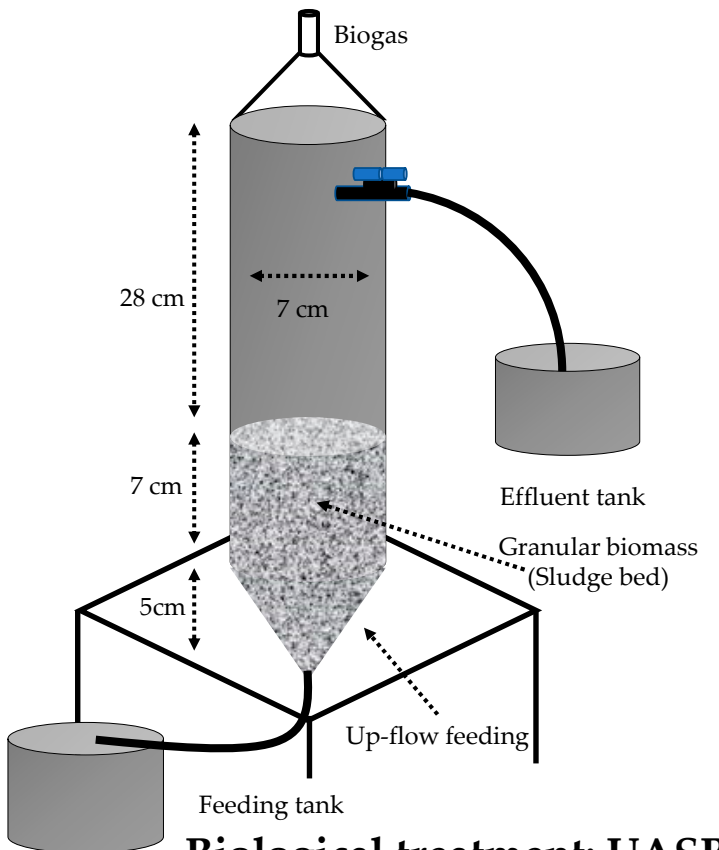

\section{Batch electrochemical systems}

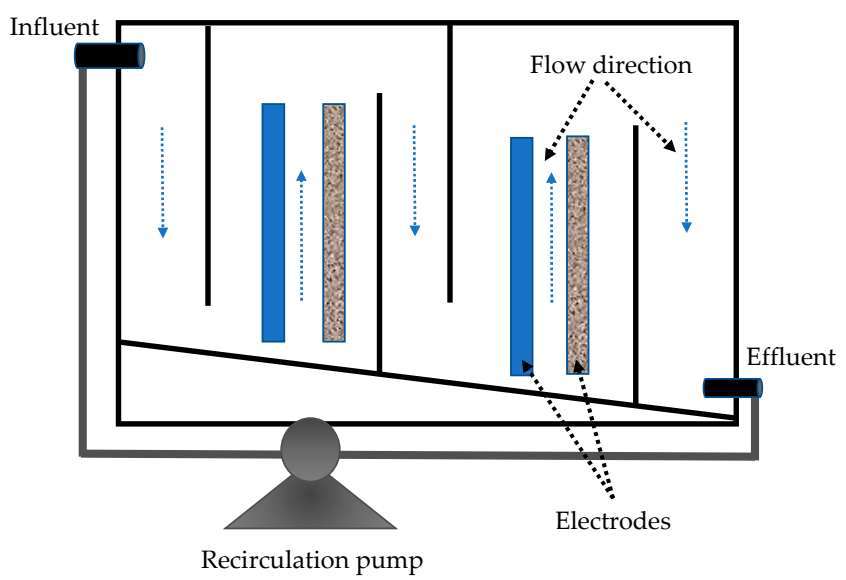

Post-treatment: EO and EC

Figure 1. Scheme of systems used for CR elimination. The left anaerobic reactor operated continuously and in the proper flow direction in the electrochemical cells operated in batch.

The electrochemical systems (electrocoagulation (EC) of $0.9 \mathrm{~L}$ and electrooxidation (EO) of $1.12 \mathrm{~L}$ ) were operated with dynamic flow interaction. That is, the liquid followed a flow direction from top to bottom and from bottom to top in 5 different sections, parallel to the electrodes and separated by walls of acrylic (Figure 1). This operation method allowed for increasing the homogenization in the system. On the other hand, two pairs of electrodes were used. For EC, anode and cathode solids of Fe and stainless steel, with an electrochemically active surface area of $110 \mathrm{~cm}^{2}$, were used. In EO, mesh electrodes were used, $\mathrm{Ti} / \mathrm{PbO}_{2}$ anodes and $\mathrm{Ti}$ cathodes, with an electrochemically active surface area of $366 \mathrm{~cm}^{2}$ and $320 \mathrm{~cm}^{2}$, respectively. The power was supplied with Single-Phase BK Precision ${ }^{\circledR}$ equipment. The color and chemical oxygen demand (COD) in the influents and effluents of the biological and ECH systems was monitored to establish the treatment efficiency. 


\subsection{Analytical Details}

Samples were collected from the influent and the effluent of the UASB reactor during 12 weeks of operation. In addition, in the electrochemical systems, samples from the influent and effluent of each experiment, according to the experimental matrix conditions (Table 1), were collected and preserved for posterior analysis. Dye concentration was evaluated in a UV spectrophotometer (Thermo Fisher Scientific, UV GENESYSTM 10S, Waltham, MA, USA) at $495 \mathrm{~nm}$. The chemical oxygen demand (COD) was determined using the colorimetric method [35]. CR and COD removal were calculated using Equations (1) and (2), respectively.

$$
\begin{gathered}
\text { CR removal }(\%)=\frac{[\mathrm{CR}]_{0}-[\mathrm{CR}]_{\mathrm{f}}}{[\mathrm{CR}]_{0}} \times 100 \\
\operatorname{COD} \text { removal }(\%)=\frac{[\mathrm{COD}]_{0}-[\mathrm{COD}]_{\mathrm{f}}}{[\mathrm{COD}]_{0}} \times 100
\end{gathered}
$$

where $\mathrm{CR}_{0}$ is the initial concentration of $\mathrm{CR}\left(\mathrm{mg} \mathrm{L}^{-1}\right), \mathrm{CR}_{\mathrm{f}}$ is the final concentration of $\mathrm{CR}$ ( $\left.\mathrm{mg} \mathrm{L}^{-1}\right), \mathrm{CR}$ removal is Congo red decolorization $(\%), \mathrm{COD}_{0}$ is the initial concentration of $\operatorname{COD}\left(\mathrm{mg} \mathrm{L}^{-1}\right), \mathrm{COD}_{\mathrm{f}}$ is the final concentration of $\mathrm{COD}\left(\mathrm{mg} \mathrm{L}^{-1}\right)$, and COD removal is the chemical oxygen demand removal (\%).

\begin{tabular}{|c|c|c|c|c|c|}
\hline \multirow[b]{2}{*}{ Coded Variables } & \multirow[b]{2}{*}{$\begin{array}{l}\text { Factors } \\
\left(\mathrm{U}_{\mathrm{i}}\right)\end{array}$} & \multicolumn{2}{|c|}{ Experimental Domain } & \multirow[b]{2}{*}{$\mathrm{U}_{\mathrm{i}, 0}$} & \multirow[b]{2}{*}{$\Delta \mathrm{U}_{\mathrm{i}}$} \\
\hline & & $\begin{array}{c}\text { Min. Value } \\
(-1)\end{array}$ & $\begin{array}{l}\text { Max. Value } \\
(+1)\end{array}$ & & \\
\hline \multicolumn{6}{|c|}{ Electrooxidation } \\
\hline$X_{1}$ & $\mathrm{U}_{1}$ : Intensity $(\mathrm{I} ; \mathrm{A})$ & 1 & 2 & 1.5 & 0.5 \\
\hline$X_{2}$ & $\mathrm{U}_{2}$ : Recirculation Flow Rate $\left(\mathrm{RFR} ; \mathrm{mL} \mathrm{min}^{-1}\right)$ & 10 & 30 & 20 & 10 \\
\hline$X_{3}$ & $\mathrm{U}_{3}:$ ExperimentalTime $(\mathrm{ET} ; \mathrm{min})$ & 60 & 140 & 100 & 40 \\
\hline \multicolumn{6}{|c|}{ Electrocoagulation } \\
\hline$X_{1}$ & $\mathrm{U}_{1}$ : Intensity $(\mathrm{I} ; \mathrm{A})$ & 1 & 2 & 1.5 & 0.5 \\
\hline$X_{2}$ & $\mathrm{U}_{2}$ : Recirculation Flow Rate (RFR; $\mathrm{mL} \min ^{-1}$ ) & 10 & 30 & 20 & 10 \\
\hline$X_{3}$ & $\mathrm{U}_{3}$ : Experimental Time (ET; min) & 10 & 25 & 17.5 & 7.5 \\
\hline
\end{tabular}

Table 1. Experimental matrix and values of independent factors.

\subsection{Experimental Design for Electrochemical Systems}

$\mathrm{CR}$ and COD degradation on the electrochemical systems was performed using response surface methodology $(\mathrm{RSM})$. Intensity $\left(\mathrm{X}_{1}, \mathrm{~A}\right)$, recirculation flow rate $\left(\mathrm{X}_{2}, \mathrm{~mL} \mathrm{~min}^{-1}\right)$, and experimental time $\left(X_{3}, \min \right)$ were the independent variables evaluated. Five levels and a total of 20 treatments comprised eight runs for factorial design, six replicates at the center point, and six runs for high and low extreme levels (Table 2). CR $\left(Y_{1}\right)$ decolorization and COD $\left(Y_{2}\right)$ removal in \% were the two investigated responses variables. Design Expert ${ }^{\circledR} 7$ (version 7.0.0) was used to generate the model and to perform the analysis variance (ANOVA). The experimental matrix and values of each independent factor are represented in Table 1. The following second-order equation gives the predicted response in all experimental fields [28,36] (Equation (3)).

$$
Y=b_{o}+\sum_{i=1}^{k} b_{i} X_{i}+\sum_{i=1}^{k} b_{i i} X_{i}^{2}+\sum_{j} \sum_{i=2}^{k} b_{i j} X_{i} X_{j}
$$

where $Y$ is the experimental response; $b_{0}$ is the average of the experimental response; Coefficients $b_{i}, b_{i i}$, and $b_{i j}$ are the linear, quadratic, and interaction effects between $i$ and $j$ factors for the response $Y$, respectively. 
Table 2. Experimental levels and factorial $2^{2}$ and central composite matrix for EO and EC.

\begin{tabular}{|c|c|c|c|c|c|c|c|c|c|c|}
\hline \multirow[b]{2}{*}{ Experiment } & \multicolumn{5}{|c|}{ Electrooxidation (EO) } & \multicolumn{5}{|c|}{ Electrocoagulation (EC) } \\
\hline & $\begin{array}{c}X_{1} \\
\text { I (A) }\end{array}$ & $\begin{array}{c}X_{2} \\
\text { RFR } \\
\left(\mathrm{mL} \mathrm{min}^{-1}\right)\end{array}$ & $\begin{array}{c}X_{3} \\
\text { ET (min) }\end{array}$ & $\begin{array}{c}Y_{1} \\
\text { CR R }(\%)\end{array}$ & $\begin{array}{c}Y_{2} \\
\operatorname{COD} R(\%)\end{array}$ & $\begin{array}{c}X_{1} \\
\text { I (A) }\end{array}$ & $\begin{array}{c}X_{2} \\
\text { RFR } \\
\left(\mathrm{mL} \mathrm{min}^{-1}\right)\end{array}$ & $\begin{array}{c}X_{3} \\
\text { ET (min) }\end{array}$ & $\begin{array}{c}Y_{1} \\
\text { CR D (\%) }\end{array}$ & $\begin{array}{c}Y_{2} \\
\text { COD } \\
\text { R }(\%)\end{array}$ \\
\hline \multicolumn{11}{|c|}{ Factorial Design } \\
\hline 1 & 1 & 10 & 60 & 10.87 & 42.62 & 1 & 10 & 10 & 33.33 & 28.95 \\
\hline 2 & 1 & 10 & 140 & 63.11 & 60.65 & 1 & 10 & 25 & 37.12 & 43.43 \\
\hline 3 & 1 & 30 & 60 & 11.28 & 45.45 & 1 & 30 & 10 & 35.12 & 30.01 \\
\hline 4 & 1 & 30 & 140 & 67.14 & 63.93 & 1 & 30 & 25 & 38.12 & 44.7 \\
\hline 5 & 2 & 10 & 60 & 48.28 & 47.54 & 2 & 10 & 10 & 50.9 & 33.97 \\
\hline 6 & 2 & 10 & 140 & 84 & 83.77 & 2 & 10 & 25 & 52.9 & 52.3 \\
\hline 7 & 2 & 30 & 60 & 55.42 & 54.09 & 2 & 30 & 10 & 49.91 & 34.91 \\
\hline 8 & 2 & 30 & 140 & 87.42 & 90.16 & 2 & 30 & 25 & 51.21 & 52.67 \\
\hline \multicolumn{11}{|c|}{ Center Points } \\
\hline 9 & 1.5 & 20 & 100 & 47.28 & 49.9 & 1.5 & 20 & 17.5 & 38.42 & 47.34 \\
\hline 10 & 1.5 & 20 & 100 & 52.85 & 52.45 & 1.5 & 20 & 17.5 & 37.87 & 48.72 \\
\hline 11 & 1.5 & 20 & 100 & 53.63 & 51.23 & 1.5 & 20 & 17.5 & 39.12 & 48.99 \\
\hline 12 & 1.5 & 20 & 100 & 53.26 & 51.5 & 1.5 & 20 & 17.5 & 38.23 & 47.34 \\
\hline 13 & 1.5 & 20 & 100 & 47.17 & 49.44 & 1.5 & 20 & 17.5 & 36.65 & 46.57 \\
\hline 14 & 1.5 & 20 & 100 & 49.51 & 48.97 & 1.5 & 20 & 17.5 & 38.32 & 47.57 \\
\hline \multicolumn{11}{|c|}{ Extreme Levels } \\
\hline 15 & 1.5 & 20 & 167.27 & 85.85 & 99 & 1.5 & 20 & 4.887 & 12.12 & 16.42 \\
\hline 16 & 1.5 & 20 & 32.72 & 15.23 & 29.98 & 1.5 & 20 & 30.11 & 52.12 & 53.49 \\
\hline 17 & 1.5 & 3.18 & 100 & 45.1 & 46.84 & 1.5 & 3.18 & 17.5 & 36.45 & 46.53 \\
\hline 18 & 1.5 & 36.81 & 100 & 48.12 & 47.11 & 1.5 & 36.81 & 17.5 & 41.93 & 49.45 \\
\hline 19 & 0.65 & 20 & 100 & 17.83 & 26.47 & 0.65 & 20 & 17.5 & 10.72 & 13.21 \\
\hline 20 & 2.34 & 20 & 100 & 91.25 & 99 & 2.34 & 20 & 17.5 & 53.61 & 54.32 \\
\hline
\end{tabular}

\section{Results and Discussion}

\subsection{Biological Treatment: Upflow Anaerobic Sludge Blanket}

Biological treatment for CR decolorization and COD removal was evaluated over $84 \mathrm{~d}$ (12 weeks) at different HRTs. The initial decolorization efficiency for CR was $80 \%$ and removal for COD $72 \%$, which gradually increased until reaching $\geq 96.6 \%$ and $\geq 84.2 \%$, respectively. The concentrations at the effluent of the UASB reactor were $3.4 \mathrm{mg} \mathrm{L}^{-1}$ of CR (from $100 \mathrm{mg} \mathrm{L}^{-1}$ of initial dye) and $158 \mathrm{mg} \mathrm{L}^{-1}$ of COD (from $1000 \mathrm{mg} \mathrm{L}^{-1}$ of initial COD), after three weeks of operation with an HRT of $12 \mathrm{~h}$ (Figure 2). Similar removal efficiency values were observed in the following stages despite the change in the TRH to $10 \mathrm{~h}$ and $8 \mathrm{~h}$, suggesting that the anaerobic sludge was already acclimated to the presence of the azo compound [37]. Under anaerobic conditions, azo compounds are susceptible to suffering reductive biotransformation by the cleavage of azo linkages, producing generally colorless but potentially dangerous aromatic amines. The reduction mechanism of azo dyes is mainly attributable to the capacity of anaerobic microorganisms to produce redox-active molecules (e.g., favines and hydroquinones) capable of transferring reducing equivalents to promote the reduction [6]. The reduction mechanism for CR suggests that three products were obtained: benzidine and two aromatic amines (with the same structure). The reduction is a two-stage process, in which the rate of benzidine production is slower than the decolorization rate, which indicates that one azo bond is broken first, promoting the decolorization, followed by a slower breaking of the second azo bond for benzidine production [38]. According to the results, CR was easily reduced by the anaerobic sludge according to the extent indicated (Figure 2). Previous studies indicate that tri-azo structures, as presented in the CR structure, are more recalcitrant compared to mono- and di-azo structures [39]. Nonetheless, the reduction of different azo dyes may occur differently, according to the toxicity extent, recalcitrance, and resistance to removal, regardless of the number of azo bonds [40]. In addition, the production of aromatic amines by the reduction in anaerobic systems treating azo compounds may result in highly toxic effluent, which makes necessary a subsequent treatment to eliminate them. Some processes, such as oxidation or adsorption systems can be applied [24,37,41]. 


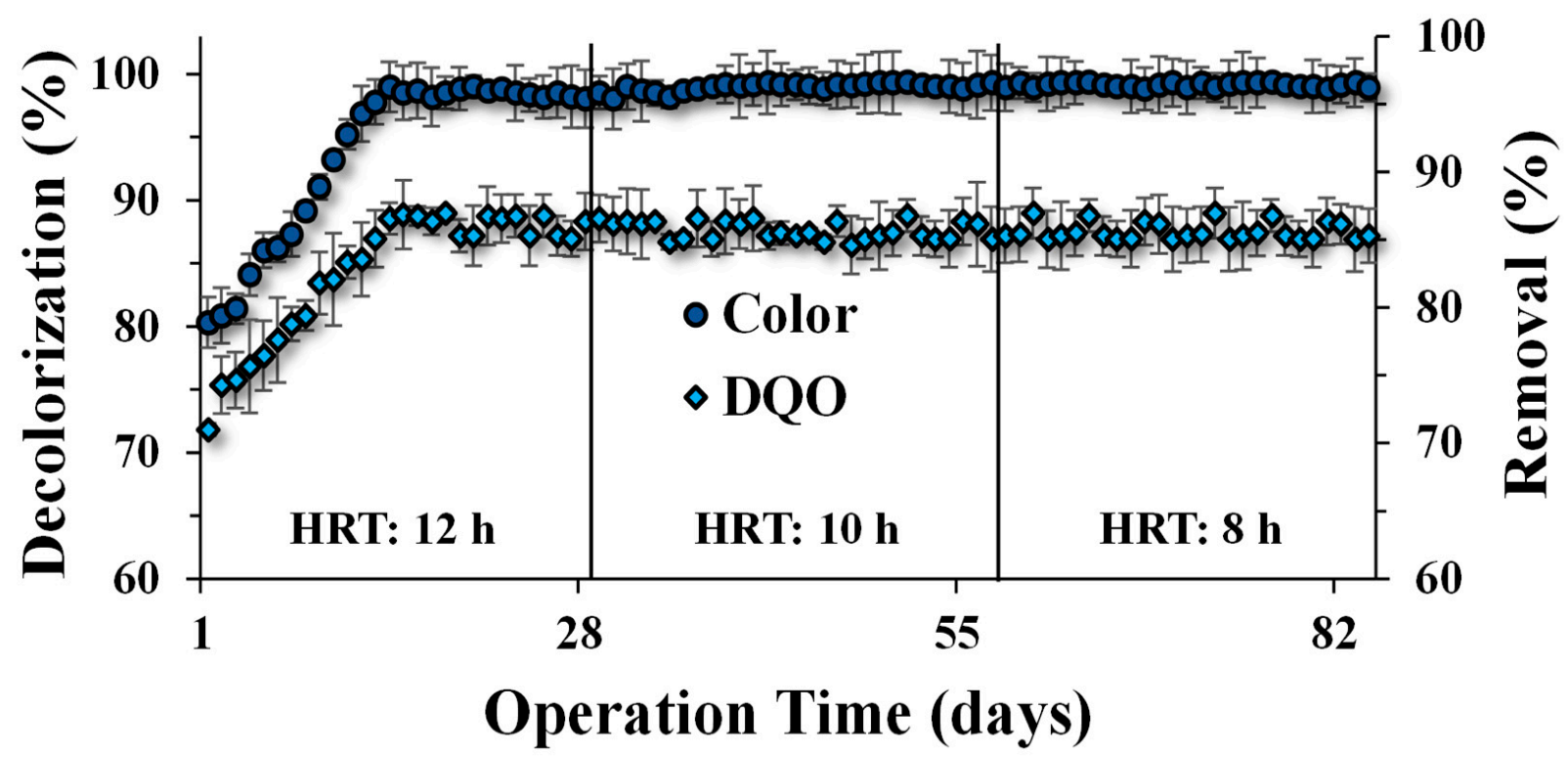

Figure 2. COD removal and CR decolorization (\%) in the UASB reactor, after 12 weeks (84 days) of operation at different hydraulic residence times: $12 \mathrm{~h}, 10 \mathrm{~h}$, and $8 \mathrm{~h}$.

\subsection{Post-Treatment Optimization: Electrochemical Systems}

3.2.1. Congo Red and Chemical Oxygen Demand Degradation in Electrooxidation Process

Three variables were evaluated: intensity $\left(X_{1}, I\right)$, recirculation flow rate $\left(X_{2}, R F R\right)$, and experimental time $\left(X_{3}, E T\right)$ on congo red $C R$ decolorization and chemical oxygen demand (COD) removal by the electrooxidation (EO) process using a response surface with a total of 20 experiments and five levels. Table 2 shows the experimental results obtained. The highest removal efficiencies were found at the higher I levels tested $(2.34 \mathrm{~A})$, at $20 \mathrm{~mL} \mathrm{~min}{ }^{-1}$ RFR and $100 \mathrm{~min}$ ET, achieving values of $91.25 \%$ for CR and $99 \%$ for COD. The lowest removal efficiencies were obtained for $\mathrm{I}=1 \mathrm{~A}$ and $0.65 \mathrm{~A}, \mathrm{RFR}=10 \mathrm{~mL} \mathrm{~min}^{-1}$ and $20 \mathrm{~mL} \mathrm{~min}^{-1}$, and ET = $60 \mathrm{~min}$ and $100 \mathrm{~min}$ for CR (10.8\%) and COD (26.4 7\%), respectively. Second-order polynomial equations are given by Equations (3) and (4) for CR and COD removal, respectively:

$$
\begin{gathered}
Y_{1}=50.52+18.03 X_{1}+21.57 X_{3}-5.05 X_{1} X_{3} \\
Y_{2}=50.50+13.54 X_{1}+16.47 X_{3}+4.47 X_{1} X_{3}+4.83 X_{1}^{2}+5.45 X_{3}^{2}
\end{gathered}
$$

Coefficients were calculated by the difference of half the arithmetic average of the highest and lowest level of results obtained. Positive coefficients have a positive effect on the response, and negative have the opposite effect [28,36]. $b_{0}=50.52$ and 50.50 in Equations (4) and (5) are the average of the responses obtained in all experiments for CR and COD removal. $b_{1}=+18.03$ and +13.54 indicate that $C R$ and COD degradation increase $36.06 \%(2 \times 18.03)$ and $27.08 \%(2 \times 13.54)$ when I increases from $1 \mathrm{~A}$ to $2 \mathrm{~A} . b_{2}=+1.47$ and +1.43 means that $\mathrm{CR}$ decolorization and COD removal increase $2.94 \%(2 \times 1.47)$ and $2.86 \%$ $(2 \times 1.43)$ when RFR increases from $10 \mathrm{~mL} \mathrm{~min}^{-1}$ to $30 \mathrm{~mL} \mathrm{~min}^{-1} . b_{3}=+21.57$ and +16.47 show that CR and COD degradation increase $43.14 \%(2 \times 21.57)$ and $32.94 \%(2 \times 16.47)$ when ET increases from $60 \mathrm{~min}$ to $140 \mathrm{~min}$.

The effect of I, RFR, and ET on CR and COD removal is shown in response surface plots (Figure 3). As observed, the decolorization of CR and removal of COD can reach $91.25 \%$ and $99 \%$ if response variables $\left(X_{1}, X_{2}\right.$, and $\left.X_{3}\right)$ are increased. For CR R and COD $\mathrm{R}$, the $p$-value model is $<0.0001$ and 0.0008 ; this indicates that the model is significant (Table 3). For CR decolorization, the $p$-value for $X_{1}$ and $X_{3}$ is $<0.0001$ (significant, $p<0.05$ with an $F$-value of 192.48 and 275.59) and for $X_{2}$ is 0.2783 (not significant). Similar results are seen for COD removal; $p$-value for $X_{1}$ and $X_{3}$ is 0.0003 and $<0.0001$ (significant, $p<0.05$, 
with an F-value of 30.26 and 44.76) and for $X_{2}$ is 0.5746 (not significant). Low dispersion is observed on data in Table 3, with a coefficient correlation value of $R^{2}=0.9735$ (for CR decolorization) and $\mathrm{R}^{2}=0.8961$ (for COD removal), which means that only $2.65 \%$ and $10.39 \%$ of variation do not belong to the models.
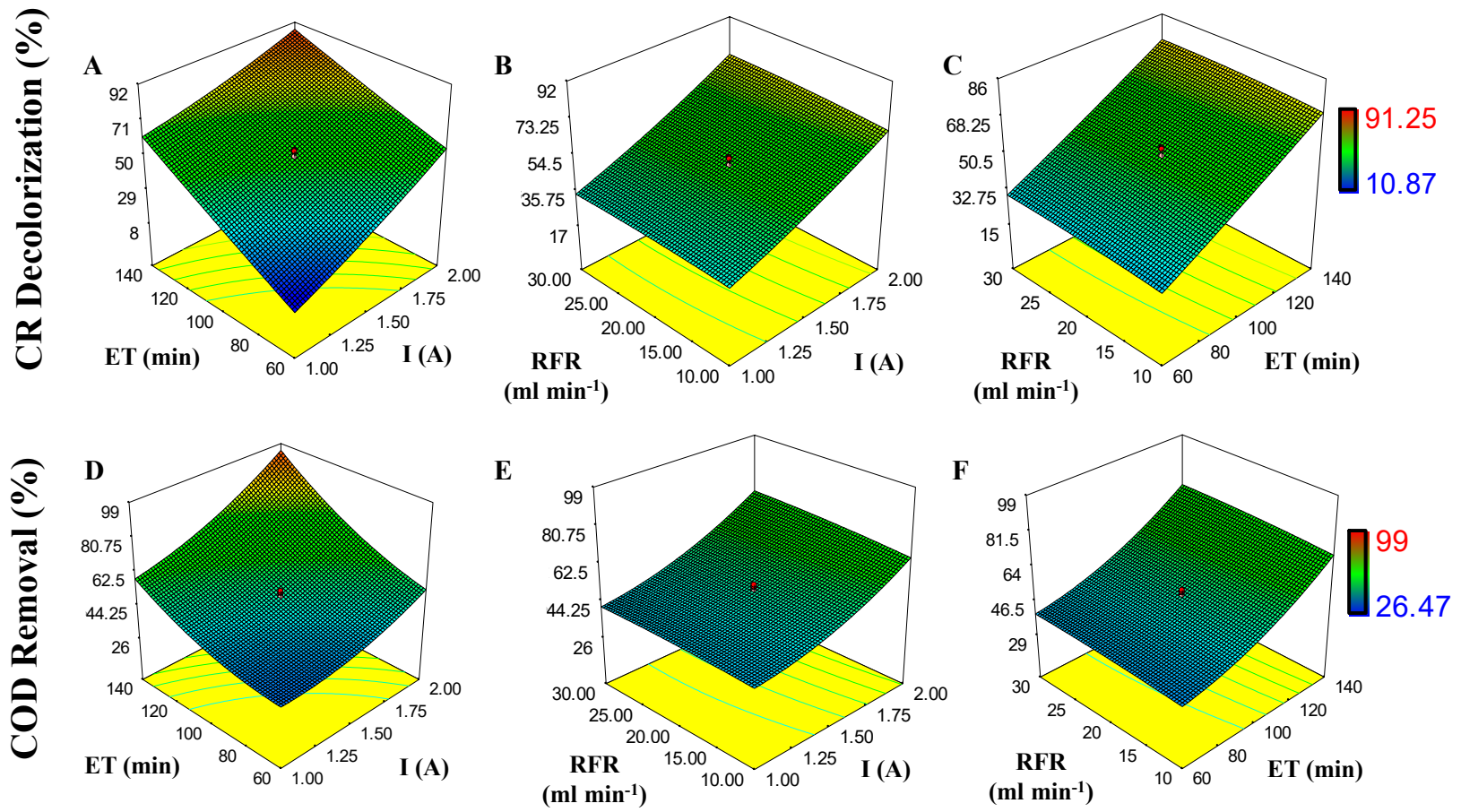

Figure 3. Effect of independent variables (I, X1; RFR, X2, and ET, X3) on response variables (CR decolorization and COD removal) during electrooxidation process (EO): (A) ET and I on CR decolorization; (B) RFR and I on CR decolorization; (C) ET and RFR on CR decolorization; (D) ET and I on COD removal; (E) RFR and I on COD removal; (F) RFR and ET on COD removal.

Table 3. ANOVA results for the response surface quadratic model for CR decolorization and COD removal in $\mathrm{EO}$ and $\mathrm{EC}$ processes.

\begin{tabular}{cccccc}
\hline \multirow{5}{*}{ Source } & \multicolumn{5}{c}{ Analysis of Variance } \\
\cline { 2 - 6 } & Sum of Square & d.f. $^{\text {a }}$ & Mean of Square & F-Value & Pr $>\boldsymbol{F}$ \\
\hline Electrooxidation & & & & \\
\hline CR R & & & & \\
Model & $11,030.79$ & 9 & 1838.47 & 192.48 & $<0.0001$ \\
$X_{1}-I$ & 4438.29 & 1 & 4438.29 & 1.28 & 0.2783 \\
$X_{2}-R F R$ & 29.52 & 1 & 29.52 & 275.59 & $<0.0001$ \\
$X_{3}-E T$ & 6354.48 & 1 & 6354.48 & 0.21 & 0.6576 \\
$X_{1} X_{2}$ & 4.68 & 1 & 4.68 & 9.08 & 0.0130 \\
$X_{1} X_{3}$ & 203.82 & 1 & 203.82 & 0.00005 & 0.9942 \\
$X_{2} X_{3}$ & 0.001 & 1 & 0.001 & 2.56 & 0.1410 \\
$X_{1}^{2}$ & 57.35 & 1 & 57.35 & 0.42 & 0.5314 \\
$X_{X}{ }^{2}$ & 9.43 & 1 & 9.43 & 0.22 & 0.6517 \\
$X_{3}{ }^{2}$ & 4.86 & 1 & 4.86 & & \\
\hline COD R & & & & & \\
Model & 7135.92 & 9 & 792.88 & 30.58 & 0.0008 \\
$X_{1}-I$ & 2503.10 & 1 & 2503.10 & 0.0003 \\
$X_{2}-R F R$ & 27.85 & 1 & 27.85 & 0.5746 \\
$X_{3}-E T$ & 3703.22 & 1 & 3703.22 & 44.76 & $<0.0001$ \\
$X_{1} X_{2}$ & 5.83 & 1 & 5.83 & 0.070 & 0.7960 \\
\hline
\end{tabular}


Table 3. Cont.

\begin{tabular}{|c|c|c|c|c|c|}
\hline \multirow{2}{*}{ Source } & \multicolumn{5}{|c|}{ Analysis of Variance } \\
\hline & Sum of Square & d.f. ${ }^{a}$ & Mean of Square & F-Value & $\operatorname{Pr}>F$ \\
\hline$X_{1} X_{3}$ & 160.12 & 1 & 160.12 & 1.94 & 0.1943 \\
\hline$X_{2} X_{3}$ & 0.011 & 1 & 0.011 & 0.0001 & 0.9912 \\
\hline$X_{1}^{2}$ & 335.58 & 1 & 335.8 & 4.06 & 0.0717 \\
\hline$X_{X}^{2}$ & 8.03 & 1 & 8.03 & 0.097 & 0.7618 \\
\hline$X_{3}^{2}$ & 427.43 & 1 & 427.43 & 5.17 & 0.0463 \\
\hline \multicolumn{6}{|c|}{ Electrocoagulation } \\
\hline \multicolumn{6}{|l|}{ CR D } \\
\hline Model & 2401.06 & 9 & 266.78 & 8.81 & 0.0011 \\
\hline$X_{1}-I$ & 673.40 & 1 & 673.40 & 22.23 & 0.0008 \\
\hline$X_{2}-R F R$ & 5.35 & 1 & 5.35 & 0.18 & 0.6831 \\
\hline $\bar{X}_{3}-E T$ & 1192.28 & 1 & 1192.28 & 39.35 & $<0.0001$ \\
\hline$X_{1} X_{2}$ & 0.13 & 1 & 0.13 & 0.004 & 0.9491 \\
\hline$X_{1} X_{3}$ & 5.99 & 1 & 5.99 & 0.20 & 0.6662 \\
\hline$X_{2} X_{3}$ & 0.016 & 1 & 0.016 & 0.0005 & 0.9820 \\
\hline$X_{1}^{2}$ & 301.86 & 1 & 301.86 & 9.96 & 0.0102 \\
\hline$X_{X}^{2}$ & 2.95 & 1 & 2.95 & 0.097 & 0.7613 \\
\hline$X_{3}^{2}$ & 248.91 & 1 & 248.91 & 8.22 & 0.0168 \\
\hline \multicolumn{6}{|l|}{ COD R } \\
\hline Model & 1835.69 & 9 & 203.97 & 2.72 & 0.0673 \\
\hline$X_{1}-I$ & 1302.31 & 1 & 1302.31 & 17.39 & 0.0019 \\
\hline$X_{2}-R F R$ & 6.37 & 1 & 6.37 & 0.085 & 0.7766 \\
\hline$X_{3}-E T$ & 438.23 & 1 & 438.23 & 5.85 & 0.0361 \\
\hline$X_{1} X_{2}$ & 3.74 & 1 & 3.74 & 0.050 & 0.8277 \\
\hline$X_{1} X_{3}$ & 1.52 & 1 & 1.52 & 0.020 & 0.8895 \\
\hline$X_{2} X_{3}$ & 0.28 & 1 & 0.28 & 0.004 & 0.9527 \\
\hline$X_{1}^{2}$ & 0.27 & 1 & 0.27 & 0.003 & 0.9537 \\
\hline$X_{2}^{2}$ & 79.46 & 1 & 79.49 & 1.06 & 0.3273 \\
\hline$X_{3}^{2}$ & 0.33 & 1 & 0.33 & 0.004 & 0.9483 \\
\hline
\end{tabular}

$\mathrm{R}^{2}=0.9735$ for CR D in EO. $\mathrm{R}^{2}=0.8961$ for COD R in EO. $\mathrm{R}^{2}=0.8880$ for CR D in EC. $\mathrm{R}^{2}=0.8917$ for COD R in EC. ${ }^{\text {a }}$ Degree of freedom.

The contribution of independent variables to response variables is expressed as a percentage and is shown in Figure 4 . The highest contribution to the response variable is $64.51 \%$ and $67.7 \%$ for $X_{3}$ and $31.43 \%$ and $22.63 \%$ for $X_{1}$ on CR decolorization and COD removal. The remainder is attributed to $X_{2}$ and interaction between variables. This high contribution in $X_{1}$ and $X_{3}$ is because they control hydroxyl radical $\left(\mathrm{OH}^{-}\right)$production in the surface anode and the other oxidants indirectly generated, such as $\mathrm{HClO}, \mathrm{H}_{2} \mathrm{~S}_{2} \mathrm{O}_{8}$, and $\mathrm{H}_{2} \mathrm{O}_{2}[28,29,42-44]$.

To establish optimal conditions in response variables, energy consumption (I) and operating time (ET) were minimized, assigning an importance of 3 out of 5 for $X_{1}$ and $\mathrm{X}_{3}$ (variables with the greatest effect in this study). Likewise, COD removal and CR decolorization were maximized, giving them an importance of 4 out of 5 and 5 out of 5 , respectively. Optimization conditions obtained were $\mathrm{I}=1.96 \mathrm{~A}, \mathrm{RFR}=23.51 \mathrm{~mL} \mathrm{~min}{ }^{-1}$, and $\mathrm{ET}=110.80 \mathrm{~min}$ to obtain a degradation of $74.12 \%$ and $73.74 \%$ of CR and COD. These conditions show that high removals can be obtained by reducing the operating conditions of the variables studied $\left(X_{1}, X_{2}\right.$, and $\left.X_{3}\right)$.

\subsubsection{CR Decolorization and COD Removal in EC Process}

For EC, the range for $X_{3}$ was reduced to 10-25 min (Table 1); this is because the EC process is faster than EO [29]. Preliminary experiments were the basis for taking $X_{3}$ values. Table 2 shows the experimental results obtained. Best degradations were found at the higher I levels tested (2.34 A), at $20 \mathrm{~mL} \mathrm{~min}^{-1} \mathrm{RFR}$ and $17.5 \mathrm{~min}$ ET with a CR decolorization 
and COD removal of $53.61 \%$ and $54.32 \%$. Second-order polynomial and lineal equations are given by Equations (6) and (7) for CR and COD degradation, respectively:

$$
\begin{gathered}
Y_{1}=47.70+7.02 X_{1}+9.34 X_{3}-4.58 X_{1}^{2}-4.16 X_{3}^{2} \\
Y_{2}=37.80+9.77 X_{1}+5.66 X_{3}
\end{gathered}
$$

Coefficients were calculated by the difference of half the arithmetic average of the highest and lowest level of the results obtained. Positive coefficients have a positive effect on the response, and negative have the opposite effect [28,36]. $b_{0}=47.70$ and 37.80 in Equations (6) and (7) are the averages of the responses obtained in all experiments for CR decolorization and COD removal.

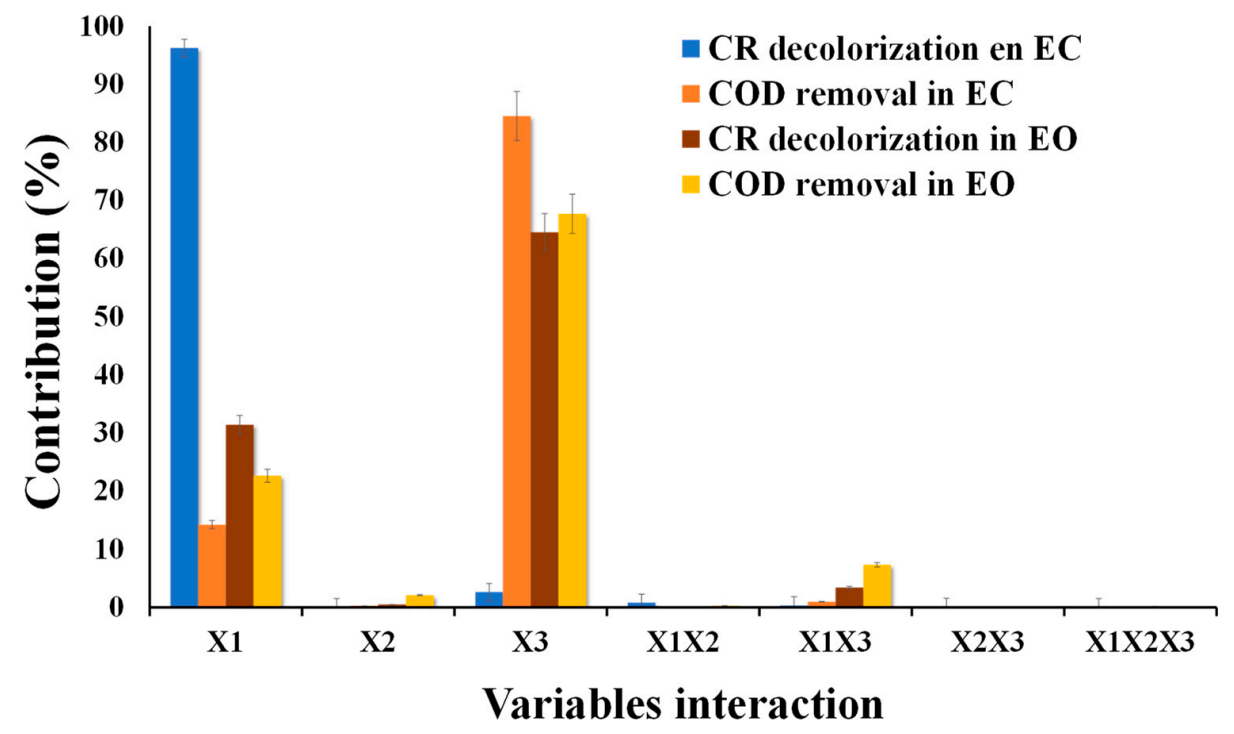

Figure 4. Contribution percentage of each variable and the interaction $\left(X_{1}, X_{2}, X_{3}, X_{1} X_{2}, X_{1} X_{3}\right.$, $X_{2} X_{3}$ ) in both electrochemical systems.

The effects of I, RFR, and ET on CR decolorization and COD removal are shown in response surface plots (Figure 5). As observed, the degradation of CR and COD can reach $53.61 \%$ and $54.32 \%$ if response variables $\left(X_{1}, X_{2}\right.$, and $\left.X_{3}\right)$ are increased. For CR and COD degradation, the $p$-value model is 0.0011 and 0.0003 ; this indicates the model is significant (significant, $p<0.05$ ). For $C R$ decolorization, the $p$-value for $X_{1}$ and $X_{3}$ is 0.0008 and for $X_{2}$ is 0.6831 (not significant). Similar results are found for COD removal, where $X_{2}$ is 0.7318 . Low dispersion is observed on data in Table 3, with a coefficient correlation value of $\mathrm{R}^{2}=0.8880$ and $\mathrm{R}^{2}=0.8961$ for $\mathrm{CR}$ and COD degradation, respectively.

The variables with the highest contribution in CR decolorization and COD removal were $X_{1}$ with $96.25 \%$ and $14.21 \%$ and $X_{3}$ with $2.61 \%$ and $84.54 \%$ (Figure 5). This is because, at high current intensity, the coagulant production increases, and pollutant entrapment takes place [45-47]. Likewise, using iron anodes, we can have coagulant species of $\mathrm{Fe}(\mathrm{OH})_{3}$, $\mathrm{Fe}(\mathrm{OH})^{2+}, \mathrm{Fe}(\mathrm{OH})_{2}{ }^{+}$, and $\mathrm{Fe}_{2}(\mathrm{OH})_{2}{ }^{4+}$ [30]. On the other hand, optimization was to minimize energy consumption (I) and operating time (ET), assigning an importance of 3 out of 5 , and response variables (COD and CR removal) were given maximium importance (4 out of 5 and 5 out of 5 , respectively). The optimization conditions obtained were $\mathrm{I}=1.98 \mathrm{~A}$, RFR $=10.10 \mathrm{~mL} \mathrm{~min}^{-1}$, and ET $=24.30 \mathrm{~min}$, to obtain a degradation of $56.01 \%$ and $54.11 \%$ of $\mathrm{CR}$ and COD. These conditions show that high removals can be obtained by reducing the operating conditions of the variables studied $\left(X_{1}, X_{2}\right.$, and $\left.X_{3}\right)$.

The low yield eliminations in EC are due to the short experimental time used (it was chosen according to the preliminary kinetics). Efficiencies can be increased by increasing the current intensity and the experimental time as these were the variables with the greatest influence and contribution to the response variables [30,47]. 

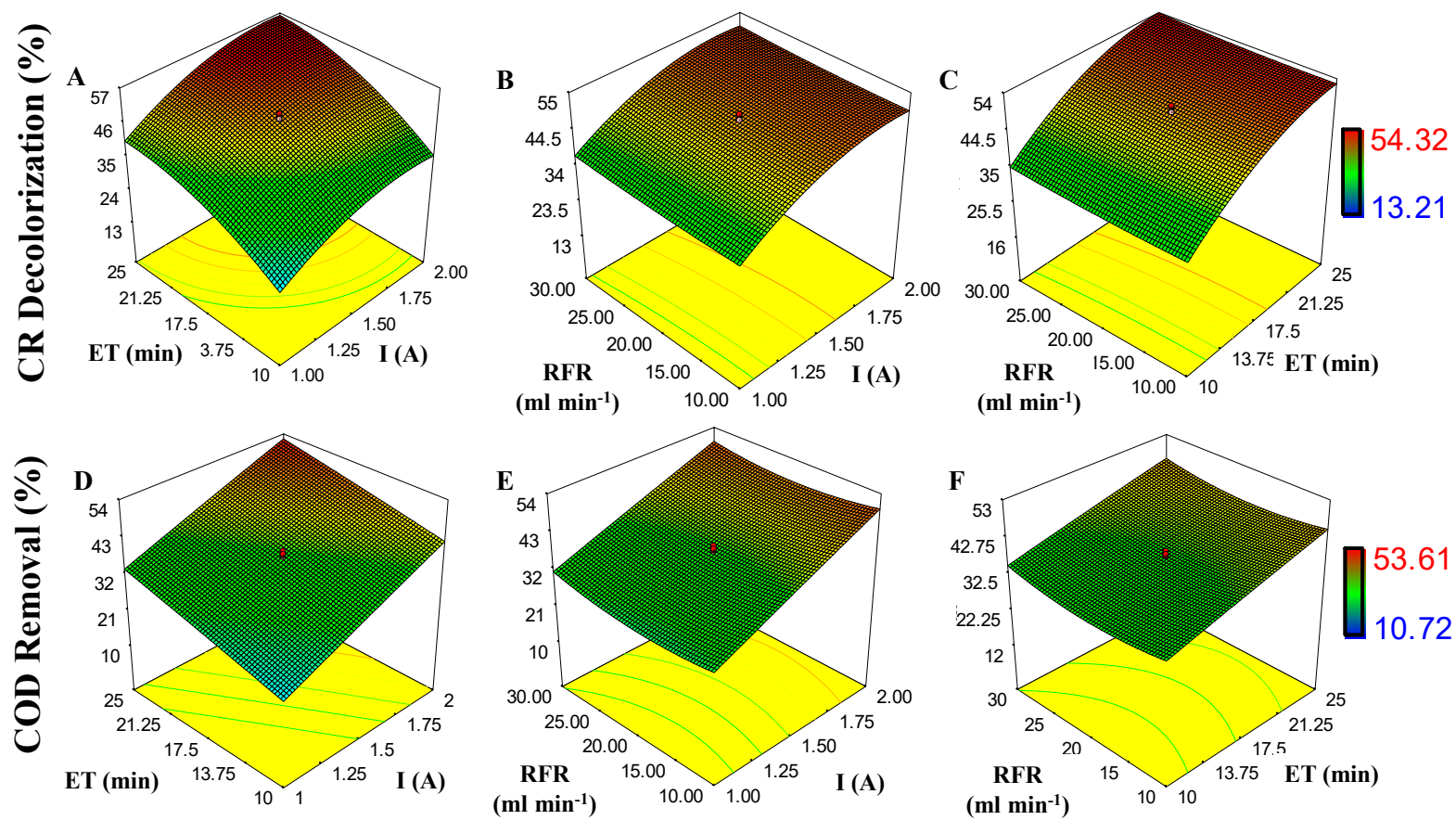

Figure 5. Effect of independent variables (I, X1; RFR, X2, and ET, X3) on response variables (CR decolorization and COD removal) during electrocoagulation process (EC): (A) ET and I on CR decolorization; (B) RFR and I on CR decolorization; (C) ET and RFR on CR decolorization; (D) ET and I on COD removal; (E) RFR and I on COD removal; and (F) RFR and ET on COD removal.

\section{3. $C R$ and COD Degradation by Coupled Biological-ECH Systems}

Total degradations for the UASB reactor coupled to EO were $99.71 \%$ for CR decolorization and $99.84 \%$ for COD removal, obtaining final concentrations of $0.29 \mathrm{mg} \mathrm{L}^{-1}$ of $\mathrm{CR}$ and $1.58 \mathrm{mg} \mathrm{L}^{-1}$ of COD. For the UASB + EC, the maximum degradations for CR and COD were $98.43 \%$ and $92.78 \%$. Previously, Aravind et al. [48] coupled the electrooxidation process to the photodegradation and biological system, achieving eliminations of $92 \%$ and $90 \%$ for color and COD degradation, respectively. Venkatesh et al. [26] used ozonation coupled to the UASB reactor for Reactive Black 5 and found a removal of $90 \%$ for COD and $94 \%$ for dye decolorization. Likewise, Buzzini et al. [31] used an inverse treatment coupling electrocoagulation to UASB, reaching $98 \%$ color and $67 \%$ COD degradation. Yetilmezsoy et al. [32] decolorized and removed the organic matter from poultry manure wastewater pretreated by a UASB and using EC as a post-treatment. They achieved degradations in the coupled system of $90 \%$ of COD and $92 \%$ of residual color. Likewise, Makwana and Ahammed [33] treated urban wastewater using a UASB coupled to an EC system, reaching removals of $71.3 \%$ for COD and $96.8 \%$ for color. The literature addresses the inverted process (electrochemical-biological); however, the by-products of these contaminants are more toxic than the original pollutant, and this limits the complete mineralization in the biological (secondary) treatment. In addition to the high degradation capacity of electrochemical systems as post-treatment, they have the advantage of occupying small spaces and do not require the addition of chemical agents [49]. In this study, anaerobic-electrochemical treatment is approached due to the azo dyes being reduced in the biological system forming the aromatic amines: benzidine and two aromatic amines (with the same structure). These amines are oxidized and desulphonated by the secondary treatment (electrooxidation) or by trapping in an adsorbent (electrocoagulation). During the electro-oxidation process, 8-Amino naphthalene diazine 3-sulfonic acid will oxidize and form metabolites (3-Hydroperoxy 8-nitrosonaphthol) [50], which will continue to oxidize until completely mineralized [51]. On EC, using iron anodes, coagulant species of $\mathrm{Fe}(\mathrm{OH})_{3}, \mathrm{Fe}(\mathrm{OH})^{2+}, \mathrm{Fe}(\mathrm{OH})_{2}{ }^{+}$, and $\mathrm{Fe}_{2}(\mathrm{OH})_{2}{ }^{4+}[30]$ are formed. These compounds trap in their matrix the amines and metabolites formed in the anaerobic system as well as the remaining color. 
The advantage of using electrooxidation for organic pollutant degradation is that complete mineralization of these compounds can be achieved up until $\mathrm{CO}_{2}$ and $\mathrm{H}_{2} \mathrm{O}$, directly by the $\mathrm{OH}^{-}$radicals generated in the anode and by other oxidants generated in the process (such as $\mathrm{HClO}, \mathrm{H}_{2} \mathrm{~S}_{2} \mathrm{O}_{8}, \mathrm{H}_{2} \mathrm{O}_{2}$, etc.) $[28,29,51]$. Likewise, methane generated in a biological treatment [40] can fully or partially supply the system demand. EO, compared to $\mathrm{EC}$, has the disadvantage that the reaction process requires more time; however, in EC, the electrodes are sacrificial; that is, they are worn during each operation. On the other hand, the EC system requires less operation time, which makes it more economical. However, if an anaerobic biological system is used as a preliminary treatment (as in this study), a large part of the energy requirement can be supplied. EC has the disadvantage of generating a coagulant to trap the pollutants. It will require a subsequent treatment to remove them from the treated effluent [29]. The coupled system evaluated in this research allowed analysis of how these electrochemical systems behave when used as post-treatment of an anaerobic system in dye decolorization. In future works, it will be essential to evaluate the methane production (in specific conditions) to know the contribution that a preliminary anaerobic treatment would have in an electrochemical system. Likewise, it is crucial to evaluate the toxicity after applying EO and EC and the degree of mineralization after applying EO.

\section{Conclusions}

The coupled system evaluated in this study improved contaminant degradation. The biological treatment system (UASB) eliminated a large concentration of CR and COD and contributed to biogas production (anaerobic system), which can be used in electrochemical cell energy requirements. When an azo bond is broken during pretreatment, it generates new pollutants (aromatic amines), which can be degraded and mineralized post-treatment (electrochemical reactors). The maximum efficiencies of sequential systems for COD removal and CR decolorization were $92.78 \%$ and $98.43 \%$ by EC and $\geq 99.84 \%$ and $\geq 99.71 \%$ by EO. The best degradation achieved was in the UASB + EO coupled system, despite the fact that this system requires more experimental time compared to the EC. The most critical variables in both electrochemical systems were I, with a $96.25 \%$ contribution in color degradation, and ET, with $84.54 \%$ in DQO removal. Likewise, EC requires treatment of subsequent sedimentation to reduce the clots present. According to the results, this coupled system can be applied and scaled to wastewater treatment with high concentrations of colorants.

Author Contributions: Conceptualization, P.G.-M., L.H.Á.-V., C.G.-G., L.A.L.-S., M.A.C.-R. and I.C.R.-S.; methodology, M.O.C.-G., R.G.U.-M., E.R.M.-E., M.A.C.-R., P.G.-M. and I.C.R.-S.; software, C.G.-G., L.H.Á.-V. and I.C.R.-S.; validation, L.H.Á.-V., C.G.-G. and I.C.R.-S.; formal analysis, P.G.-M., L.M.D.-T., C.G.-G., L.A.L.-S., L.H.Á.-V. and I.C.R.-S.; investigation, P.G.-M., M.A.C.-R., M.O.C.G., C.G.-G., L.H.Á.-V. and I.C.R.-S.; resources, L.A.L.-S., C.G.-G., L.H.Á.-V., M.O.C.-G., P.G.-M., L.M.D.-T. and M.A.C.-R.; data curation, E.R.M.-E., L.A.L.-S., L.H.Á.-V., R.G.U.-M. and I.C.R.-S.; writing-original draft preparation, C.G.-G., L.H.Á.-V., P.G.-M., M.O.C.-G., M.A.C.-R. and I.C.R.S.; writing-review and editing, P.G.-M., C.G.-G., L.H.Á.-V., M.O.C.-G., M.A.C.-R. and I.C.R.-S.; visualization, R.G.U.-M., L.H.Á.-V. and E.R.M.-E. All authors have read and agreed to the published version of the manuscript.

Funding: This research received no external funding.

Institutional Review Board Statement: Not applicable.

Informed Consent Statement: Not applicable.

Data Availability Statement: Not applicable.

Conflicts of Interest: The authors declare no conflict of interest. 


\section{References}

1. Carvalho, J.R.S.; Amaral, F.M.; Florencio, L.; Kato, M.T.; Delforno, T.P.; Gavazza, S. Microaerated UASB reactor treating textile wastewater: The core microbiome and removal of azo dye Direct Black 22. Chemosphere 2020, 242, 125157. [CrossRef]

2. Ausavasukhi, A.; Kampoosaen, C.; Kengnok, O. Adsorption characteristics of Congo red on carbonized leonardite. J. Clean. Prod. 2016, 134, 506-514. [CrossRef]

3. Zhang, L.; Song, F.; Wang, S.; Wang, H.; Yang, W.; Li, Y. Efficient Removal of Hexavalent Chromium and Congo Red by Graphene Oxide/Silica Nanosheets with Multistage Pores. J. Chem. Eng. Data 2020, 65, 4354-4368. [CrossRef]

4. Taher, T.; Rohendi, D.; Mohadi, R.; Lesbani, A. Congo red dye removal from aqueous solution by acid-activated bentonite from sarolangun: Kinetic, equilibrium, and thermodynamic studies. Arab J. Basic Appl. Sci. 2019, 26, 125-136. [CrossRef]

5. Bedekar, P.A.; Saratale, R.G.; Saratale, G.D.; Govindwar, S.P. Development of low cost upflow column bioreactor for degradation and detoxification of Blue HERD and textile effluent by Lysinibacillus sp. RGS immobilized on Loofa. Int. Biodeterior. Biodegrad. 2014, 96, 112-120. [CrossRef]

6. Cervantes, F.J.; Dos Santos, A.B. Reduction of azo dyes by anaerobic bacteria: Microbiological and biochemical aspects. Rev. Environ. Sci. Bio/Technol. 2011, 10, 125-137. [CrossRef]

7. Shu, J.; Wang, Z.; Huang, Y.; Huang, N.; Ren, C.; Zhang, W. Adsorption removal of Congo red from aqueous solution by polyhedral $\mathrm{Cu} 2 \mathrm{O}$ nanoparticles: Kinetics, isotherms, thermodynamics and mechanism analysis. J. Alloys Compd. 2015, 633, 338-346. [CrossRef]

8. Vimonses, V.; Lei, S.; Jin, B.; Chow, C.W.K.; Saint, C. Kinetic study and equilibrium isotherm analysis of Congo Red adsorption by clay materials. Chem. Eng. J. 2009, 148, 354-364. [CrossRef]

9. Islam, M.A.; Mozumder, M.S.I. Development of Treatment Technology for Dye Containing Industrial Wastewater. J. Sci. Res. 2010, 2, 567.

10. Han, R.; Ding, D.; Xu, Y.; Zou, W.; Wang, Y.; Li, Y.; Zou, L. Use of rice husk for the adsorption of congo red from aqueous solution in column mode. Bioresour. Technol. 2008, 99, 2938-2946. [CrossRef] [PubMed]

11. Mittal, A.; Mittal, J.; Malviya, A.; Gupta, V.K. Adsorptive removal of hazardous anionic dye "Congo red" from wastewater using waste materials and recovery by desorption. J. Colloid Interface Sci. 2009, 340, 16-26. [CrossRef]

12. El Haddad, M.; Regti, A.; Slimani, R.; Lazar, S. Assessment of the biosorption kinetic and thermodynamic for the removal of safranin dye from aqueous solutions using calcined mussel shells. J. Ind. Eng. Chem. 2014, 20, 717-724. [CrossRef]

13. Ranjbar, D.; Raeiszadeh, M.; Lewis, L.; MacLachlan, M.J.; Hatzikiriakos, S.G. Adsorptive removal of Congo red by surfactant modified cellulose nanocrystals: A kinetic, equilibrium, and mechanistic investigation. Cellulose 2020, 27, 3211-3232. [CrossRef]

14. Rahman, N.U.; Ullah, I.; Alam, S.; Khan, M.S.; Shah, L.A.; Zekker, I.; Burlakovs, J.; Kallistova, A.; Pimenov, N.; Vincevica-Gaile, Z.; et al. Activated Ailanthus altissima Sawdust as Adsorbent for Removal of Acid Yellow 29 from Wastewater: Kinetics Approach. Water 2021, 13, 2136. [CrossRef]

15. Umar, A.; Khan, M.S.; Alam, S.; Zekker, I.; Burlakovs, J.; dC Rubin, S.S.; Bhowmick, G.D.; Kallistova, A.; Pimenov, N.; Zahoor, M. Synthesis and Characterization of Pd-Ni Bimetallic Nanoparticles as Efficient Adsorbent for the Removal of Acid Orange 8 Present in Wastewater. Water 2021, 13, 1095. [CrossRef]

16. Dassanayake, R.S.; Acharya, S.; Abidi, N. Recent Advances in Biopolymer-Based Dye Removal Technologies. Molecules 2021, 26, 4697. [CrossRef] [PubMed]

17. Singh, R. Role of Azoreductases in Bacterial Decolorization of Azo Dyes. Curr. Trends Biomed. Eng. Biosci. 2017, 9, 50-52. [CrossRef]

18. Zaroual, Z.; Azzi, M.; Saib, N.; Chainet, E. Contribution to the study of electrocoagulation mechanism in basic textile effluent. J. Hazard. Mater. 2006, 131, 73-78. [CrossRef]

19. Isik, M.; Sponza, D.T. Effects of alkalinity and co-substrate on the performance of an upflow anaerobic sludge blanket (UASB) reactor through decolorization of Congo Red azo dye. Bioresour. Technol. 2005, 96, 633-643. [CrossRef] [PubMed]

20. Alvarez, L.H.; Arvizu, I.C.; Garcia-Reyes, R.B.; Martinez, C.M.; Olivo-Alanis, D.; Del Angel, Y.A. Quinone-functionalized activated carbon improves the reduction of congo red coupled to the removal of p-cresol in a UASB reactor. J. Hazard Mater. 2017, 338, 233-240. [CrossRef]

21. Silva, S.Q.; Silva, D.C.; Lanna, M.C.; Baeta, B.E.; Aquino, S.F. Microbial dynamics during azo dye degradation in a UASB reactor supplied with yeast extract. Braz. J. Microbiol. 2014, 45, 1153-1160. [CrossRef]

22. Dos Santos, A.B.; Cervantes, F.J.; van Lier, J.B. Review paper on current technologies for decolourisation of textile wastewaters: Perspectives for anaerobic biotechnology. Bioresour. Technol. 2007, 98, 2369-2385. [CrossRef] [PubMed]

23. Somasiri, W.; Li, X.F.; Ruan, W.Q.; Jian, C. Evaluation of the efficacy of upflow anaerobic sludge blanket reactor in removal of colour and reduction of COD in real textile wastewater. Bioresour. Technol. 2008, 99, 3692-3699. [CrossRef]

24. Lu, X.; Liu, R. Treatment of Azo Dye-Containing Wastewater Using Integrated Processes. In Biodegradation of Azo Dyes; Atacag Erkurt, H., Ed.; Springer: Berlin/Heidelberg, Germany, 2010; pp. 133-155.

25. Sathishkumar, K.; AlSalhi, M.S.; Sanganyado, E.; Devanesan, S.; Arulprakash, A.; Rajasekar, A. Sequential electrochemical oxidation and bio-treatment of the azo dye congo red and textile effluent. J. Photochem. Photobiol. B 2019, 200, 111655. [CrossRef] [PubMed]

26. Venkatesh, S.; Venkatesh, K.; Quaff, A.R. Dye decomposition by combined ozonation and anaerobic treatment: Cost effective technology. J. Appl. Res. Technol. 2017, 15, 340-345. [CrossRef] 
27. Katsoni, A.; Mantzavinos, D.; Diamadopoulos, E. Coupling digestion in a pilot-scale UASB reactor and electrochemical oxidation over BDD anode to treat diluted cheese whey. Environ. Sci. Pollut. Res. 2014, 21, 12170-12181. [CrossRef] [PubMed]

28. Romero-Soto, I.C.; Dia, O.; Leyva-Soto, L.A.; Drogui, P.; Buelna, G.; Diaz-Tenorio, L.M.; Ulloa-Mercado, R.G.; Gortares-Moroyoqui, P. Degradation of Chloramphenicol in Synthetic and Aquaculture Wastewater Using Electrooxidation. J. Environ. Qual. 2018, 47, 805-811. [CrossRef]

29. Drogui, P.; Blais, J.A.; Mercier, G. Review of Electrochemical Technologies for Environmental Applications. Recent Pat. Eng. 2007, 1, 257-272. [CrossRef]

30. Akhtar, A.; Aslam, Z.; Asghar, A.; Bello, M.M.; Raman, A.A.A. Electrocoagulation of Congo Red dye-containing wastewater: Optimization of operational parameters and process mechanism. J. Environ. Chem. Eng. 2020, 8, 104055. [CrossRef]

31. Buzzini, A.P.; Patrizzi, L.J.; Motheo, A.J.; Pires, E.C. Preliminary evaluation of the electrochemical and chemical coagulation processes in the post-treatment of effluent from an upflow anaerobic sludge blanket (UASB) reactor. J. Environ. Manag. 2007, 85, 847-857. [CrossRef]

32. Yetilmezsoy, K.; Sakar, S. Improvement of COD and color removal from UASB treated poultry manure wastewater using Fenton's oxidation. J. Hazard. Mater. 2008, 151, 547-558. [CrossRef]

33. Makwana, A.R.; Ahammed, M.M. Electrocoagulation process for the post-treatment of anaerobically treated urban wastewater. Sep. Sci. Technol. 2017, 52, 1412-1422. [CrossRef]

34. Alvarez, L.H.; Cervantes, F.J. Assessing the impact of alumina nanoparticles in an anaerobic consortium: Methanogenic and humus reducing activity. Appl. Microbiol. Biotechnol. 2012, 95, 1323-1331. [CrossRef]

35. APHA. Standard Methods for the Examination of Water and Wastewater; Public Health Association: Washington, DC, USA, 1999.

36. García-Gómez, C.; Drogui, P.; Zaviska, F.; Seyhi, B.; Gortáres-Moroyoqui, P.; Buelna, G.; Neira-Sáenz, C.; Estrada-alvarado, M.; Ulloa-Mercado, R.G. Experimental design methodology applied to electrochemical oxidation of carbamazepine using $\mathrm{Ti} / \mathrm{PbO} 2$ and Ti/BDD electrodes. J. Electroanal. Chem. 2014, 732, 1-10. [CrossRef]

37. Ong, S.-A.; Toorisaka, E.; Hirata, M.; Hano, T. Decolorization of azo dye (Orange II) in a sequential UASB-SBR system. Sep. Purif. Technol. 2005, 42, 297-302. [CrossRef]

38. Olivo-Alanis, D.; Garcia-Reyes, R.B.; Alvarez, L.H.; Garcia-Gonzalez, A. Mechanism of anaerobic bio-reduction of azo dye assisted with lawsone-immobilized activated carbon. J. Hazard. Mater. 2018, 347, 423-430. [CrossRef]

39. $\mathrm{Hu}, \mathrm{T}$.L. Kinetics of azoreductase and assessment of toxicity of metabolic products from azo dyes by Pseudomonas luteola. Water Sci. Technol. A J. Int. Assoc. Water Pollut. Res. 2001, 43, 261-269. [CrossRef]

40. Alvarez, L.H.; Valdez-Espinoza, R.; García-Reyes, R.B.; Olivo-Alanis, D.; Garza-González, M.T.; Meza-Escalante, E.R.; GortáresMoroyoqui, P. Decolorization and biogas production by an anaerobic consortium: Effect of different azo dyes and quinoid redox mediators. Water Sci. Technol. A J. Int. Assoc. Water Pollut. Res. 2015, 72, 794-801. [CrossRef] [PubMed]

41. Bras, R.; Gomes, A.; Ferra, M.I.; Pinheiro, H.M.; Goncalves, I.C. Monoazo and diazo dye decolourisation studies in a methanogenic UASB reactor. J. Biotechnol. 2005, 115, 57-66. [CrossRef] [PubMed]

42. Faouzi, M.; Cañizares, P.; Gadri, A.; Lobato, J.; Nasr, B.; Paz, R.; Rodrigo, M.A.; Saez, C. Advanced oxidation processes for the treatment of wastes polluted with azoic dyes. Electrochim. Acta 2006, 52, 325-331. [CrossRef]

43. Faouzi Elahmadi, M.; Bensalah, N.; Gadri, A. Treatment of aqueous wastes contaminated with Congo Red dye by electrochemical oxidation and ozonation processes. J. Hazard. Mater. 2009, 168, 1163-1169. [CrossRef] [PubMed]

44. GilPavas, E.; Dobrosz-Gómez, I.; Gómez-García, M.-Á. Efficient treatment for textile wastewater through sequential electrocoagulation, electrochemical oxidation and adsorption processes: Optimization and toxicity assessment. J. Electroanal. Chem. 2020, 878, 114578. [CrossRef]

45. Zaied, M.; Bellakhal, N. Electrocoagulation treatment of black liquor from paper industry. J. Hazard. Mater. 2009, 163, 995-1000. [CrossRef] [PubMed]

46. Pajootan, E.; Arami, M.; Mahmoodi, N.M. Binary system dye removal by electrocoagulation from synthetic and real colored wastewaters. J. Taiwan Inst. Chem. Eng. 2012, 43, 282-290. [CrossRef]

47. Wei, M.-C.; Wang, K.-S.; Huang, C.-L.; Chiang, C.-W.; Chang, T.-J.; Lee, S.-S.; Chang, S.-H. Improvement of textile dye removal by electrocoagulation with low-cost steel wool cathode reactor. Chem. Eng. J. 2012, 192, 37-44. [CrossRef]

48. Aravind, P.; Subramanyan, V.; Ferro, S.; Gopalakrishnan, R. Eco-friendly and facile integrated biological-cum-photo assisted electrooxidation process for degradation of textile wastewater. Water Res. 2016, 93, 230-241. [CrossRef]

49. Al-Qodah, Z.; Al-Qudah, Y.; Assirey, E. Combined biological wastewater treatment with electrocoagulation as a post-polishing process: A review. Sep. Sci. Technol. 2020, 55, 2334-2352. [CrossRef]

50. Telke, A.; Joshi, S.; Jadhav, S.; Shah, D.; Govindwar, S. Decolorization and detoxification of Congo red and textile industry effluent by an isolated bacterium Pseudomonas sp. SU-EBT. Biodegradation 2009, 21, 283-296. [CrossRef] [PubMed]

51. Tran, N.; Drogui, P. Electrochemical removal of microcystin-LR from aqueous solution in the presence of natural organic pollutants. J. Environ. Manag. 2013, 114, 253-260. [CrossRef] [PubMed] 